\title{
AN EVALUATION OF KARADI SHEEP FLEECES
}

\author{
( Received: 26.3. 2008 )
}

\author{
By \\ K. O. Aziz and A. A. Hama* \\ Department of Animal Resources, College of Agriculture, University of Salahaddin- Erbil, Iraq. \\ * Department of Animal Resources, College of Agriculture, University of Sulaimani, Iraq.
}

\begin{abstract}
One hundred and seventy three Karadi sheep (139 ewes \& 34 rams) aged 1.5 to $\geq 5.5$ years kept on three private flocks were used to study the effect of flock, sex, age and ewe status on body weight and wool physical traits and the relationships among them. Skin samples were also obtained for histological study. The overall mean of follicle density, S:P ratio, body weight, greasy fleece weight, clean wool\%, staple length, fiber length, fiber diameter, crimps, medullated fibers, outercoat fibers, undercoat fibers and kemp fibers were respectively, $17.6 / \mathrm{mm}^{2}, 3.2,58.1 \mathrm{~kg}, 1.8 \mathrm{~kg}, 78.4 \%, 9.1 \mathrm{~cm}, 12.8 \mathrm{~cm}, 30.8 \mu \mathrm{m}, 1.14$ crimps $/ \mathrm{cm}, 4.2 \%, 72.2 \%, 19.7 \%$ and $8.2 \%$. Furthermore, it was noticed that the grease content in greasy wool was $4.2 \%$. Statistical analysis revealed a significant effect of flock on most wool physical traits. Males were significantly heavier than females and had heavier greasy fleece weight, longer lengths and higher outercoat fibers but lower undercoat fibers. Age affects body weight, greasy fleece weight, lengths, fiber diameter and kemp fibers and ewe status affect body weight, clean wool percentage, lengths and crimps significantly. The correlations among Karadi wool traits bring an attention to the possible improvement of this type of fleece by selection.
\end{abstract}

Key words: follicle, karadi sheep, wool traits

\section{INTRODUCTION}

Sheep in Iraq represent the most important livestock in the country and are raised for meat, milk and wool and the annual revenue of such products are about 60,25 and $15 \%$, respectively (Haddadin, 1977) in addition to benefit from its manure. The Karadi (Kurdi) sheep like other Iraqi breeds (Awassi \& Arabi) belong to the fat-tailed and carpet-wool type, and contribute $18-20 \%$ of the country sheep population. They are native to the undulating dry-farming plains and mountainous region of Iraqi Kurdistan which is characterized by its Mediterranean climatic conditions. Karadi sheep have several indigenous strains. The animals of the mountain flocks are ordinary smaller in size than sheep of the plains (Juma and Alkass, 2000).

The variation in raw wool is caused by complicated interactions of genetical and environmental factors (Ryder \& Stephenson, 1968). The importance of raw wool characteristics on price, processing stages and end-products is well known and reviewed (Ince, 1978; Nasrullah, 1983; Kurdo, 1985 and Champion and Robards, 1999).

Due to the availability of limited and conflicting information on the fleece properties of Karadi sheep (Ghoneim et al., 1974; Ashmawy and Al-Azzawi, 1982a\&b; Aziz, 1991), this study aimed to evaluate Karadi sheep fleeces in Sulaimani Governorate in terms of skin histology, live weight, wool physical properties and grease/wax content and to determine the effects of non-genetical factors (flock, sex, age and ewe status) on these traits, and the relationships among them.

\subsection{Histological studies}

\section{MATERIALS AND METHODS}

A $1 \mathrm{~cm}^{2}$ skin specimens from four body regions namely; anterior, mid and posterior of the side and the mid of the back of each of 15 Karadi ewes, 3-4 year old was taken and fixed in 10\% formalin solution neutral buffered for 24-48 hrs. After histological processing (James, 1976), sections of 5-8 $\mathrm{mm}$ thickness were prepared and stained with Hematoxylin-Eosin. Primary and secondary wool follicles $/ \mathrm{mm}^{2}$ were counted by a Hamilton Electron Microscope using S-Spline2 computer program and imaged with GKB Digital Camera.

\subsection{Raw wool studies}

One hundred and seventy three randomly selected Karadi sheep (139 ewes \& 34 rams) from three private flocks in Sulaimani Governorate were hand- sheared at the beginning of May, 
2005. The sheep aged 1.5 to $\geq 5.5$ years and the ewes were either barren, rearing single or twin lambs. Although the managerial practices in terms of feeding and husbandry differed among flocks, the sheep feeding depended on pasture, green grass and cereal stubble. In addition, supplement of barley grain and wheat straw was offered during winter.

Immediately after shearing, each animal was weighed and greasy fleece weight was recorded to the nearest 0.5 and $0.1 \mathrm{~kg}$, respectively, and approximately $50 \mathrm{~g}$ of wool sample were taken from its right mid-side. The average staple length from five staples of each greasy wool sample was estimated, by a ruler, from their cut base to the midway in the pyramid formed by the tip (Von Bergen, 1963). About 10g of greasy wool from each sample were conditioned $(65 \pm 2 \%$ R.H. \& $20 \pm 2 \mathrm{c}^{\circ}$ for $24 \mathrm{hrs}$.) prior to scouring in non-ionic detergent, and clean wool was determined as the percentage of scoured oven dry at $16 \%$ regain to the weight of conditioned greasy sample. One hundred and fifty fibers were randomly drawn from a degreased staple and used for fiber length measurements, while an average number of crimps $/ \mathrm{cm}$ was measured from ten selected fibers. The diameter of 200-300 fibers was measured by projection microscope (Lanameter) from each sample in accordance to the ASMTT (1978). The medullation percentage was estimated by counting the number of medullated fibers occurring in the sample used for measuring the diameter as described by the IWTO (1976). Also, the weight of the different fiber types (outercoat, undercoat \& kemp fibers) was determined by visual separation of one degreased staple by applying the method of Doney and Smith (1961).

\subsection{Statistical analysis}

Data were analyzed using the General Linear Model (GLM) procedure (SAS, 1998). Different mathematical models were used, in accordance to the studied traits. The correlations among traits were also computed. The differences between means of subclasses were tested by Duncan's multiple range test using GLM of SAS (1998).

\section{RESULTS AND DISCUSSION}

\subsection{Follicle traits}

Karadi primary $(\mathrm{P})$ and secondary (S) wool follicles were arranged in groups as shown in Figure (1). The overall mean of the number of primary, secondary and total follicle density $(\mathrm{P}+\mathrm{S}) / \mathrm{mm}^{2}$ and secondary: primary ratio were 4.3, 13.3, 17.6 and 3.2 respectively (Table1). Body site had a significant $(\mathrm{P} \leq 0.01)$ effect on $\mathrm{S}$ : $\mathrm{P}$ ratio, being the highest at the anterior-side (3.7) and the lowest at the posterior-side (2.7). The above results were similar to those observed in Awassi sheep by Hassan et al. (1995). However, Karadi follicle density was found to be lower than Australian Romney (18.9) but higher than other Australian carpet wool breeds (i.e., Drysdale, 14.4;Carpetmaste, 14.6;Elliottdale, 15.3;Tukidale, 16.1) as found by Champion \& Robards (2000) and Indian breeds (i.e., Chokla, 9.4 \& Malpura, 5.6) as stated by Narayan (1960). The value of $S$ : $\mathrm{P}$ ratio was found to be lower than the range of 5.8-8.6 for the above Australian carpet wool breeds but higher than Indian breeds (i.e., Chokla, $2.1 \&$ Malpura, 1.3). Due to the values of midside that were similar to the overall mean and its highly significant $(\mathrm{P} \leq 0.01)$ correlation, it appears that the samples from the mid-side could be used as a representative of the body.

Table (1): Least square means \pm S.E. of body sites affecting follicle traits together with the correlations between mid-side values and overall mean for each trait.

\begin{tabular}{|c|c|c|c|c|c|c|}
\hline \multirow[t]{2}{*}{ Traits } & \multirow{2}{*}{$\begin{array}{c}\text { Overall } \\
\text { mean }\end{array}$} & \multicolumn{4}{|c|}{ Body sites } & \multirow{2}{*}{$\begin{array}{c}\text { Simple } \\
\text { correlation }\end{array}$} \\
\hline & & Anterior-side & Mid-side & Posterior-side & Mid-back & \\
\hline $\begin{array}{l}\text { Primary } \\
\text { follicles } / \mathrm{mm}^{2}\end{array}$ & $4.3 \pm 0.15$ & $3.7 \pm 0.20^{\mathrm{B}}$ & $4.3 \pm 0.27^{\mathrm{AB}}$ & $4.5 \pm 0.35^{\mathrm{AB}}$ & $4.7 \pm 0.32^{\mathrm{A}}$ & $* * .836$ \\
\hline $\begin{array}{l}\text { Secondary } \\
\text { Follicles } / \mathrm{mm}^{2}\end{array}$ & $13.3 \pm 0.34$ & $13.5 \pm 0.56^{\mathrm{AB}}$ & $13.3 \pm 0.70^{\mathrm{AB}}$ & $11.9 \pm 0.79^{\mathrm{B}}$ & $14.4 \pm 0.51^{\mathrm{A}}$ & $* * .802$ \\
\hline $\begin{array}{l}\text { Follicle } \\
\text { density/mm }\end{array}$ & $17.6 \pm 0.45$ & $17.3 \pm 0.73^{\mathrm{AB}}$ & $17.5 \pm 0.93^{\mathrm{AB}}$ & $16.3 \pm 1.08^{\mathrm{B}}$ & $19.1 \pm 0.72^{\mathrm{A}}$ & $* * .814$ \\
\hline S:P Ratio & $3.2 \pm 0.08$ & $3.7 \pm 0.13^{\mathrm{a}}$ & $3.2 \pm 0.12^{\mathrm{b}}$ & $2.7 \pm 0.13^{c}$ & $3.2 \pm 0.19^{b}$ & $* * .783$ \\
\hline
\end{tabular}

Values within the same row with different small letters are significantly different $(\mathrm{P} \leq 0.01)$.

Values within the same row with different capital letters are significantly different $(\mathrm{P} \leq 0.05)$.

Alcohol extractable matter (grease content) from greasy wool sample was determined for each age group by Soxhlet extraction following the instructions and procedures adopted by the IWTO (1976).

\subsection{Body weight}

Table (2) indicates that the overall mean of body weight of Karadi sheep was $58.1 \mathrm{~kg}$ with an average of $53.3 \mathrm{~kg}$ and $77.6 \mathrm{~kg}$ for ewes and rams, respectively. In comparison to other Iraqi local 
breeds, Karadi sheep is heavier than Awassi and Arabi breeds (Juma \& Alkass, 2000) but lighter than its strain (Hamadani) as stated by Aziz \& AlOramary (2005).

\subsection{Wool physical characteristics}

The results presented in Table (2) show that
The overall mean of staple length and fiber length were found to be 9.1 and $12.8 \mathrm{~cm}$, respectively. The average staple length and fiber length for ewes were 8.8 and $12.6 \mathrm{~cm}$ while for rams were 10.1 and $13.7 \mathrm{~cm}$, respectively, this might be due to slower growth of the fiber in

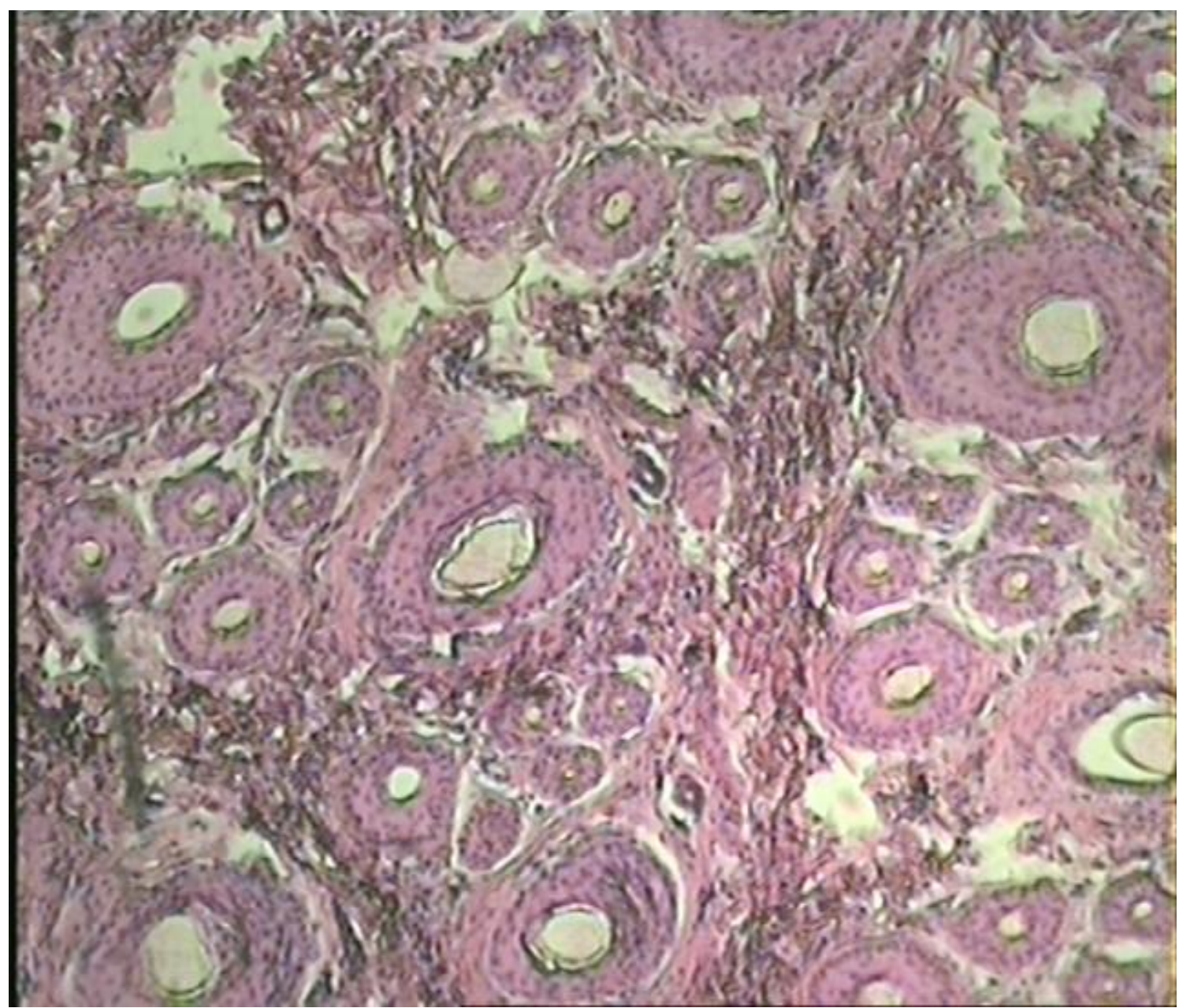

Fig.(1): Primary (large) and secondary (small ) karadi wool follicles.

the overall mean of greasy fleece weight was 1.8 $\mathrm{kg}$. The average fleece weight was $1.7 \mathrm{~kg}$ and $2.4 \mathrm{~kg}$ for ewes and rams, respectively. However, earlier findings for fleece weight on the same breed were $1.5 \& 2.2 \mathrm{~kg}$ (Ashmawy and AlAzzawi, 1982a; Aziz, 1991). Rams surpass ewes in this trait could be mainly due to their greater size.

The overall mean of clean wool percentage was $78.4 \%$; being $77.6 \%$ for ewes and $81.8 \%$ for rams. This high value is associated with low wax content due to low S: P follicle ratio of the Karadi sheep. The present result corresponds with the earlier findings of other Iraqi local breeds (Ghoneim et al., 1967; Aziz, 1991\&1993; Aziz \& Al-Oramary, 2005) except than that reported by Ashmawy \& Al-Azzawi (1982a), who observed a range of 48.9 and $57.5 \%$, which might be due 185 the differences in the source of samples. ewes due to their physiological status (Ryder, 1975). The average staple length and fiber length recorded in the current study were shorter than that reported by other studies (Ghoneim et al., 1974; Ashmawy and Al-Azzawi, 1982b; Aziz, 1991) for the same breed. Such differences might be attributed to the environmental and technical factors.

The overall mean of fiber diameter was $30.8 \mu \mathrm{m}$. The average fiber diameter for ewes and rams were $30.4 \mu \mathrm{m}$ and $32.6 \mu \mathrm{m}$, respectively. Similar value $(30.7 \mu \mathrm{m})$ was reported by Ashmawy and Al-Azzawi (1982b), whereas higher values $(37.2 \& 48.1 \mu \mathrm{m})$ were reported by Aziz (1991) and Ghoneim et al. (1974). This difference might be due to the environmental and technical factors, in addition to genetic variation, since this breed has many strains raised under the same name. The wide range of 
Table (2): Least square means \pm S.E. of factors affecting body weight and wool physical characteristics.

\begin{tabular}{|c|c|c|c|c|c|c|c|c|c|}
\hline Sheep variables & No. & $\begin{array}{c}\text { Body weight } \\
\text { (kg) }\end{array}$ & $\begin{array}{c}\text { Greasy fleece } \\
\text { weight.(kg) }\end{array}$ & $\begin{array}{c}\text { Clean wool } \\
(\%)\end{array}$ & $\begin{array}{l}\text { Staple length } \\
\text { (cm) }\end{array}$ & $\begin{array}{c}\text { Fiber length } \\
(\mathrm{cm})\end{array}$ & $\begin{array}{c}\text { Fiber } \\
\text { diameter }(\mu \mathrm{m})\end{array}$ & Crimps/cm & $\begin{array}{c}\text { Medullated } \\
\text { fibers (\%) }\end{array}$ \\
\hline Overall mean & 173 & $58.1 \pm 0.95$ & $1.8 \pm 0.04$ & $78.4 \pm 1.03$ & $9.1 \pm 0.15$ & $12.8 \pm 0.17$ & $30.8 \pm 0.50$ & $1.14 \pm 0.02$ & $4.2 \pm 0.29$ \\
\hline \multicolumn{10}{|l|}{ Flock } \\
\hline 1 & 58 & $62.2 \pm 1.83^{\mathrm{a}}$ & $2.0 \pm 0.06^{\mathrm{a}}$ & $88.4 \pm 0.92^{a}$ & $8.3 \pm 0.23^{b}$ & $13.0 \pm 0.25^{A}$ & $30.3 \pm 0.64^{B}$ & $1.17 \pm 0.03^{\mathrm{a}}$ & $3.8 \pm 0.35^{A}$ \\
\hline 2 & 63 & $55.3 \pm 1.35^{b}$ & $1.6 \pm 0.07^{b}$ & $80.8 \pm 1.27^{b}$ & $9.2 \pm 0.27^{\mathrm{a}}$ & $12.4 \pm 0.32^{A}$ & $29.7 \pm 0.57^{B}$ & $1.21 \pm 0.03^{\mathrm{a}}$ & $4.7 \pm 0.48^{A}$ \\
\hline 3 & 52 & $56.9 \pm 1.63^{b}$ & $1.9 \pm 0.08^{\mathrm{a}}$ & $64.5 \pm 1.52^{c}$ & $9.8 \pm 0.21^{\mathrm{a}}$ & $13.2 \pm 0.31^{A}$ & $32.8 \pm 1.29^{A}$ & $1.02 \pm 0.02^{b}$ & $4.1 \pm 0.66^{A}$ \\
\hline \multicolumn{10}{|l|}{ Sex } \\
\hline Ewes & 139 & $53.3 \pm 0.59^{b}$ & $1.7 \pm 0.04^{b}$ & $77.6 \pm 1.19^{A}$ & $8.8 \pm 0.15^{b}$ & $12.6 \pm 0.19^{b}$ & $30.4 \pm 0.58^{A}$ & $1.17 \pm 0.02^{\mathrm{a}}$ & $4.0 \pm 0.32^{A}$ \\
\hline Rams & 34 & $77.6 \pm 1.86^{a}$ & $2.4 \pm 0.09^{a}$ & $81.8 \pm 1.77^{A}$ & $10.1 \pm 0.35^{\mathrm{a}}$ & $13.7 \pm 0.35^{\mathrm{a}}$ & $32.6 \pm 0.86^{A}$ & $1.02 \pm 0.04^{b}$ & $5.0 \pm 0.64^{\mathrm{A}}$ \\
\hline \multicolumn{10}{|l|}{ Age (year) } \\
\hline 1.5 & 34 & $50.0 \pm 1.27^{b}$ & $1.7 \pm 0.06^{B}$ & $80.3 \pm 1.53^{A}$ & $9.2 \pm 0.37^{\mathrm{ab}}$ & $13.3 \pm 0.33^{A}$ & $29.5 \pm 0.91^{B}$ & $1.21 \pm 0.04^{A}$ & $4.7 \pm 0.72^{A}$ \\
\hline 2.5 & 38 & $56.9 \pm 2.11^{\mathrm{a}}$ & $2.0 \pm 0.10^{A}$ & $75.7 \pm 2.38^{A}$ & $9.7 \pm 0.27^{\mathrm{a}}$ & $13.0 \pm 0.38^{\mathrm{AB}}$ & $29.9 \pm 0.69^{B}$ & $1.13 \pm 0.04^{A}$ & $3.9 \pm 0.59^{A}$ \\
\hline 3.5 & 41 & $62.0 \pm 2.23^{a}$ & $1.9 \pm 0.08^{\mathrm{AB}}$ & $77.2 \pm 2.25^{\mathrm{A}}$ & $9.3 \pm 0.26^{\mathrm{ab}}$ & $12.9 \pm 0.37^{\mathrm{AB}}$ & $30.8 \pm 0.71^{\mathrm{AB}}$ & $1.12 \pm 0.04^{A}$ & $3.6 \pm 0.53^{A}$ \\
\hline 4.5 & 33 & $61.0 \pm 1.97^{\mathrm{a}}$ & $1.8 \pm 0.11^{\mathrm{AB}}$ & $78.6 \pm 2.54^{A}$ & $8.6 \pm 0.37^{b c}$ & $12.7 \pm 0.39^{\mathrm{AB}}$ & $33.4 \pm 1.93^{A}$ & $1.15 \pm 0.05^{A}$ & $4.4 \pm 0.65^{A}$ \\
\hline 5.5 & 27 & $60.3 \pm 2.11^{a}$ & $1.7 \pm 0.09^{B}$ & $81.5 \pm 2.66^{A}$ & $8.3 \pm 0.34^{c}$ & $12.0 \pm 0.24^{B}$ & $30.8 \pm 0.98^{\mathrm{AB}}$ & $1.07 \pm 0.05^{A}$ & $4.9 \pm 0.81^{\mathrm{A}}$ \\
\hline \multicolumn{10}{|l|}{ Ewe status $\mathbb{\|}$} \\
\hline Barren & 21 & $47.2 \pm 1.19^{C}$ & $1.6 \pm 0.06^{A}$ & $83.1 \pm 1.84^{A}$ & $9.0 \pm 0.49^{A}$ & $13.3 \pm 0.33^{A}$ & $28.4 \pm 1.12^{A}$ & $1.32 \pm 0.05^{\mathrm{A}}$ & $3.6 \pm 0.65^{A}$ \\
\hline $\begin{array}{l}\text { Rearing single } \\
\text { lambs }\end{array}$ & 106 & $53.9 \pm 0.65^{B}$ & $1.7 \pm 0.04^{A}$ & $75.7 \pm 1.42^{B}$ & $8.9 \pm 0.16^{A}$ & $12.6 \pm 0.23^{\mathrm{AB}}$ & $30.9 \pm 0.70^{A}$ & $1.15 \pm 0.02^{B}$ & $4.2 \pm 0.40^{A}$ \\
\hline $\begin{array}{l}\text { Rearing twin } \\
\text { lambs }\end{array}$ & 12 & $58.4 \pm 1.59^{A}$ & $1.7 \pm 0.10^{A}$ & $85.3 \pm 3.66^{A}$ & $7.8 \pm 0.49^{B}$ & $11.8 \pm 0.49^{B}$ & $29.9 \pm 1.24^{A}$ & $1.11 \pm 0.06^{B}$ & $3.5 \pm 0.63^{A}$ \\
\hline
\end{tabular}

Values within the same column with different small letters are significantly different $(\mathrm{P} \leq 0.01)$.

Values within the same column with different capital letters are significantly different $)$. ( $\mathrm{P} \leq 0.05)$.I was in the mathematical model for ewes only. 
fiber diameter among the fleeces of karadi sheep is due to the fact that this breed was not selected for its wool production.

The overall mean of the number of crimps was $1.14 \mathrm{crimps} / \mathrm{cm}$. This is in agreement with that observed by Ghoneim et al. (1974).

The overall mean of medullated fiber percentage was $4.2 \%$ with the range of zero to $19.3 \%$. Higher values $(6.8-19.5 \%)$ were reported earlier by Ghoneim et al. (1974), Ashmawy and Al-Azzawi (1982b) and Aziz (1991).

Table (3) indicates that the overall means of outercoat, undercoat and kemp fibers percentage by weight, are $72.2,19.7$ and $8.2 \%$, respectively with the range of $(30.1-93.9 \%),(3.9-50.3 \%)$ and $(0.0-52.0 \%)$ for the above traits, respectively. Lower values $(2.3 \& 2.9 \%)$ for average kemp fibers were reported by Aziz (1991) and Ashmawy and Al-Azzawi (1982a). The high variation of kemp fibers among fleeces, suggest the possibility of eliminating kemp fibers content by a proper breeding program.

\subsection{Alcohol extractable matter}

Alcohol extractable matter content for greasy wool at different age groups is presented in Figure (2), which tends to decrease after 3.5 years old. The average value was found to be $4.2 \%$. Lower values (1.7\%) and (0.4-1.5\%) for Hamadani and Pakistani carpet wool sheep were reported, respectively by Aziz \& Al-Oramary (2005) and Hasnain (1985). The low wax content is associated with low S: P follicle ratio of the carpet wool sheep (Fraser \& Short, 1960).

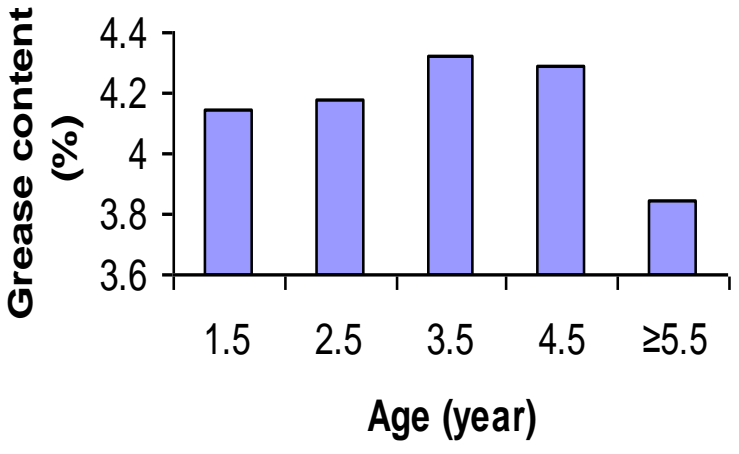

Fig. (2): Grease content in Karadi sheep fleece

\subsection{Factors affecting the studied traits}

A significant effect of flock $(\mathrm{P} \leq 0.05)$ on fiber diameter and a high significant effect $(\mathrm{P} \leq 0.01)$ on all studied traits except fiber length and medullated fiber percentages was observed (Tables $2 \& 3$ ). This may be attributed to different management practices followed in each flocks, in addition to differences in genotype as the Karadi sheep is not pure breed. Hence, raw wool variability is highly influenced by environmental and genetical factors (Ryder \& Stephenson, 1968).

The effect of sex appeared to be significant $(\mathrm{P} \leq 0.01)$ on most studied traits. The superiority of rams over ewes in body weight is due to difference in sex hormones (Owen, 1976), and in wool production which might be attributed to the larger size of the rams compared to ewes and to

Table (3): Least squares means \pm S.E.of factors affecting fiber type ratio by weight

\begin{tabular}{|c|c|c|c|c|}
\hline Sheep variables & No. & Outercoat fibers (\%) & Undercoat fibers (\%) & Kemp fibers (\%) \\
\hline Overall mean & 173 & $72.2 \pm 0.92$ & $19.7 \pm 0.66$ & $8.2 \pm 0.57$ \\
\hline \multicolumn{5}{|l|}{$\begin{array}{l}\text { Flock } \\
\end{array}$} \\
\hline 1 & 58 & $71.0 \pm 1.36^{b}$ & $19.4 \pm 1.04^{\text {ab }}$ & $9.6 \pm 0.85^{\mathrm{a}}$ \\
\hline 2 & 63 & $68.9 \pm 1.71^{b}$ & $22.1 \pm 1.14^{\mathrm{a}}$ & $9.0 \pm 1.17^{\mathrm{a}}$ \\
\hline 3 & 52 & $77.4 \pm 1.43^{\mathrm{a}}$ & $17.1 \pm 1.17^{b}$ & $5.5 \pm 0.76^{b}$ \\
\hline \multicolumn{5}{|l|}{ Sex } \\
\hline Ewes & 139 & $70.8 \pm 1.05^{b}$ & $20.6 \pm 0.75^{\mathrm{a}}$ & $8.7 \pm 0.68^{A}$ \\
\hline Rams & 34 & $77.8 \pm 1.53^{a}$ & $16.1 \pm 1.25^{b}$ & $6.1 \pm 0.73^{A}$ \\
\hline \multicolumn{5}{|l|}{ Age(year) } \\
\hline 1.5 & 34 & $72.5 \pm 1.82^{A}$ & $20.5 \pm 1.24^{A}$ & $7.0 \pm 1.00^{B}$ \\
\hline 2.5 & 38 & $72.8 \pm 1.78^{A}$ & $20.5 \pm 1.46^{A}$ & $6.8 \pm 0.85^{\mathrm{B}}$ \\
\hline 3.5 & 41 & $73.6 \pm 1.71^{A}$ & $19.4 \pm 1.37^{\mathrm{A}}$ & $7.1 \pm 0.98^{B}$ \\
\hline 4.5 & 33 & $71.1 \pm 2.29^{A}$ & $19.3 \pm 1.62^{A}$ & $9.6 \pm 1.50^{\mathrm{AB}}$ \\
\hline 5.5 & 27 & $70.1 \pm 2.99^{A}$ & $18.6 \pm 1.81^{\mathrm{A}}$ & $11.4 \pm 2.12^{\mathrm{A}}$ \\
\hline \multicolumn{5}{|l|}{ Ewe status II } \\
\hline Barren & 21 & $71.3 \pm 2.44^{\mathrm{A}}$ & $20.6 \pm 1.60^{A}$ & $8.1 \pm 1.39^{A}$ \\
\hline Rearing single lambs & 106 & $70.8 \pm 1.23^{A}$ & $20.8 \pm 0.89^{A}$ & $8.5 \pm 0.80^{A}$ \\
\hline Rearing twin lambs & 12 & $69.8 \pm 3.45^{A}$ & $18.9 \pm 2.19^{A}$ & $11.3 \pm 2.44^{\mathrm{A}}$ \\
\hline
\end{tabular}

Values within the same column with different small letters are significantly different $(\mathrm{P} \leq 0.01)$.

Values within the same column with different capital letters are significantly different $(\mathrm{P} \leq 0.05)$.

II was in the mathematical model for ewes only. 
the physiological status of the ewes (Ryder, 1975; Yeates et al., 1975).

Age of animal showed a significant effect $(\mathrm{P} \leq 0.05)$ on fleece weight, fiber length, fiber diameter and kemp fibers and highly significant effect $(P \leq 0.01)$ on body weight and staple length. In general, a slight increase in most traits with advancing age up to the third or fourth year old and thereafter decline was observed in the current work. Similar trends were reported (Aziz, 1993; Juma \& Alkass, 2000; Alkass et al., 2003; Aziz and Al-Oramary, 2005). The low productivity of older group (5.5 years) may be attributed to low feed intake, consequently low follicle efficiency, in addition to the effects of reproduction (Yeates et al., 1975).

Ewe status had a significant effect $(\mathrm{P} \leq 0.05)$ on body weight, clean wool percentage, staple length and fiber length. The possible explanation is that most of the barren ewes were aged 1.5 year.

\subsection{Correlation analysis}

The correlations among the studied characteristics are given in Table (4). The value of correlation between body weight and greasy fleece weight $(0.49, \mathrm{P} \leq 0.01)$ was similar to that observed by Maarof (1989) and Aziz\& AlOramary (2005) for Hamadani sheep but was higher than those of other Iraqi breeds (Awassi \& Arabi) which were 0.19 and 0.33 (Juma \& Alkass, 1996 and Al-Saigh et al., 1992, respectively). The highly significant $(\mathrm{P} \leq 0.01)$ positive correlations between the greasy fleece weight and each of the staple length (0.35), fiber length (0.41) and outercoat fibers (0.37) from one side and the highly significant $(\mathrm{P} \leq 0.01)$ negative correlation between the greasy fleece weight and the undesirable kemp fibers $(-0.33)$ from the other side may possibly increase the efficiency of selecting individuals for heavy fleece weight but lower kemp fiber content.

\section{Conclusions}

It is clear from the study that Karadi sheep belongs to the carpet-wool type and produce low quantity of wool with high contamination of undesirable kemp fibers. However, the large variations in wool physical traits suggest that Karadi sheep are not selected for fleece characteristics. The highly significant and negative correlations existed between kemp fibers and most studied traits will assist breeders in the improvement of wool production quantitatively and qualitatively by initiating a selection program.

\section{Acknowledgements}

The authors are very grateful to each of Dr. Ausama M. Al-Naimee, Dept. of Biology, College of Science, Univ.of Mosul and Dr. Ali H. Hassan, College of Veterinary Medicine, Univ. of Sulaimani and also to the staff of the Histopathology Laboratory of Martyr Saefadeen Consultative Hospital at Sulaimani for histology technical assistance. This study was supported by Univ.of Sulaimani.

\section{REFERENCES}

Alkass J.E., Al-Azzawi W.A.R. and Ali S.H. (2003). A study on some wool traits in different genetic groups of sheep. Iraqi J.Agric.Sci., 34 (1): 253-256.

Al-Saigh M.N.R., Al-Amin S.K. and Hanna W.J. (1992). Some factors affecting fleece weight of Arabi sheep. Basrah.J.Agric.Sci., 5 (2): 139143.

Ashmawy G.M. and Al-Azzawi W.A. (1982a). A comparative study of fleece characterestics in Iraqi sheep, I.Greasy -fleece weight, shrinkage $\%$ and fiber type ratio. Egypt. J.Anim.Prod., 22 (1): 53-61.

Ashmawy G.M. and Al-Azzawi W.A. (1982b). A comparative study of fleece characterestics in

Table (4): Correlation coefficients for body weight and studied wool physical characteristics of karadi sheep.

\begin{tabular}{|l|c|c|c|c|c|c|c|c|c|}
\hline \multicolumn{1}{|c|}{ Character } & $\begin{array}{c}\text { Greasy } \\
\text { fleece } \\
\text { weight }\end{array}$ & $\begin{array}{c}\text { Staple } \\
\text { length }\end{array}$ & $\begin{array}{c}\text { Fiber } \\
\text { length }\end{array}$ & $\begin{array}{c}\text { Fiber } \\
\text { diameter }\end{array}$ & Crimps & $\begin{array}{c}\text { Medullated } \\
\text { fibers }\end{array}$ & $\begin{array}{c}\text { Outercoat } \\
\text { fibers }\end{array}$ & $\begin{array}{c}\text { Undercoat } \\
\text { fibers }\end{array}$ & $\begin{array}{c}\text { Kemp } \\
\text { fibers }\end{array}$ \\
\hline Body weight & $.49^{* *}$ & .11 & .06 & .13 & $-.23^{* *}$ & .11 & .07 & $-.15^{* *}$ & .06 \\
\hline $\begin{array}{l}\text { Greasy fleece } \\
\text { weight }\end{array}$ & & $.35^{* *}$ & $.41^{* *}$ & .10 & $-.32^{* *}$ & -.06 & $.37^{* *}$ & $-.23^{* *}$ & $-.33^{* *}$ \\
\hline Staple length & & & $.42^{* *}$ & $.25^{* *}$ & $-.40^{* *}$ & .09 & $.49^{* *}$ & $-.43^{* * *}$ & $-.30^{* * *}$ \\
\hline Fiber length & & & & $.17^{* *}$ & $-.31^{* *}$ & -.11 & $.52^{* *}$ & $-.29^{* * *}$ & $-.50^{* *}$ \\
\hline Fiber diameter & & & & & $-.37^{* *}$ & $.20^{* *}$ & $.23^{* *}$ & $-.28^{* * *}$ & -.04 \\
\hline Crimps & & & & & & -.09 & $-.46^{* *}$ & $.42^{* *}$ & .25 \\
\hline $\begin{array}{l}\text { Medullated } \\
\text { fibers }\end{array}$ & & & & & & $-.15^{*}$ & -.04 & $.28^{* * *}$ \\
\hline $\begin{array}{l}\text { Outercoat } \\
\text { fibers }\end{array}$ & & & & & & & $-.78^{* *}$ & $-.69^{* *}$ \\
\hline $\begin{array}{l}\text { Undercoat } \\
\text { fibers }\end{array}$ & & & & & & & & & .10 \\
\hline
\end{tabular}


Iraqi sheep, II.Fiber diameter, medullated fibers \% and fiber length. Egypt. J.Anim.Prod., 22 (1): 63-71.

ASMTT. (1978). Australian Standard Method of Test for Textile, A.S.2001. 2.1,Determination of mean fiber diameter of textile fibers by projection microscope.

Aziz K.O. (1991). Some wool physical characteristics of Karadi sheep. Mesopotamia, J.Agric., 23 (3): 5-9.

Aziz K.O. (1993). Some wool quality traits of Hamadani sheep. Mesopotamia, J.Agric., 25 (4): 5-9.

Aziz K.O. and Al-Oramary R.A.S. (2005). A study on fleece characterization of Hamadani sheep in Erbil plain. Mesopotamia, J.Agric., 33 (1): 3-12.

Champion S.C. and Robards G.E. (1999). The Australian speciality carpet wool breeds, their wool and its role in carpet manufacture.Wool Tech.Sheep Breed., 47 (1): 1-18.

Champion S.C. and Robards G.E. (2000). Follicle characteristics, seasonal carpet changes in fiber cross-sectional area and ellipticity in Australian specialty wool sheep, Romneys and Merinos. Small Ruminant Res., 38: 71-82.

Doney J.M. and Smith W.F. (1961). The fleece of the Scottish Blackface sheep.1.Seasonal changes in wool production and fleece structure. J.Agric.Sci.Camb., 56: 365-374.

Fraser A.S. and Short B.F. (1960). The biology of the fleece. CSIRO. Australia. Anim. Res. Lab. Tech. Paper No.3: 15.

Ghoneim K.E., Ashmawy G.E.M. and ElMekkawi F. (1967). Some physical properties of Awasi fleeces. Mesopotamia, J.Agric. and Forestry Res.,2 (1): 1-7.

Ghoneim K.E., Kazzal N.T. and Abdallah R.K.H. (1974). Some wool characteristics of Karadi sheep in northern Iraq. J.Agric.Sci.Camb., 83: 171-174.

Haddadin S.H. (1977). Effect of Crossbreeding Between Awassi and Karadi Sheep on Body Weight Dimensions and Some Wool Traits. M.Sc. Thesis,College of Agric. \& Forestry, Univ.of Mosul, Iraq.

Hasnain H.U. (1985). Sheep and goats in Pakistan. FAO, Anim.Prod.and Health, paper No.56, Rome: 46.

Hassan A.A.A., Al-Kass J.E., Al-Jassim R.A.M. and Khamas W.A. (1995). Wool follicle population in Awassi sheep. Iraqi J.Agric.Sci., 26 (1): 126-129.
Ince J. (1978). The characteristics of carpet wools in relation to processing and performance. In: Carpet wools-carpet manufacture. (ed.by Story L.F.). Proceedings of a seminar held at the wool exchange, Christchurch, New Zealand. April 10-11: 59-69.

IWTO (1976). International Wool Textile Organization, Technical Committee, Specification of Test Methods (12-64 (E)\&19$76(\mathrm{E}))$.

James J. (1976). Light Microscopic Techniques in Biology and Medicine. (cited from Junqueira L.C., Carneiro J. and Kelley R.O. (1992). Basic Histology $7^{\text {th }}$ ed. Printed in the United States of America. Paper 1-14).

Juma K.H and Alkass J.E. (1996). Awassi sheep in Iraq. Dirasat Agric. Sci., 23: 200-207.

Juma K.H and Alkass J.E. (2000). Sheep in Iraq. The Arab Center for the Studies of Arid Zones and Dry Lands(ACSAD). Damascus.

Kurdo K.O.A. (1985). The Role of Resistance to Compression in the Processing of Superfine Wool on the Worsted System. Ph.D.Thesis, Univ. of New South Wales, Australia.

Maarof N.N. (1989). A study on wool characteristics of Hamadani rams. Iraqi J.Agric. Sci., 20 (2): 51-59.

Narayan S. (1960). Skin follicle types, ratios and population densities in Rajasthan sheep breeds.Aust.J.Agric.Res., 11 (3): 408-426 (Abstr.).

Nasrullah M.S. (1983). Studies of the Properties and Processing Behaviour of Wool from Iraqi Breeds of Sheep.Ph.D.Thesis, Univ.of Bradford, West Yorkshire.

Owen J.B. (1976). Sheep Production. Bailliere and Tindall, London.

Ryder M.L. (1975). Development,structure and seasonal change in the fleeces of unimproved Scottish Blackface sheep. J.Agric.Sci.Camb., 85: 85-92.

Ryder M.L. and Stephenson S.K. (1968). Wool Growth. Acad. press.Inc. London: 562-592.

SAS. (1998). Statistical Analysis System.User's Guide.Version 7. Statistics.SAS Institute Inc. Cary, NC. USA.

Von Bergen W. (1963). Wool Handbook. $3^{\text {rd }}$ ed. V1. John Wiley \& Sons Inc.,New York, London: 752.

Yeates N.T.M., Edy T.M. and Hill M.K. (1975). Animal Science. Pergamon Press.New South Wiles, Australia: 345-346. 


\author{
تقويم جزة الأغنام الكرادية \\ قاسم عمر عزيز - آرزو عبدالله حمه

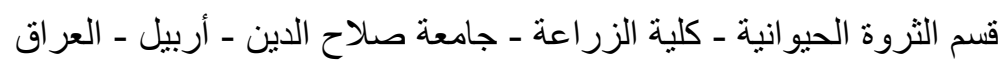

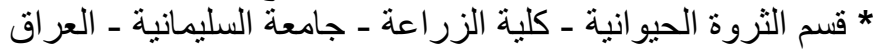

ملخص

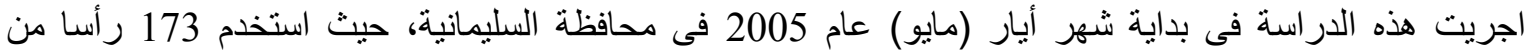

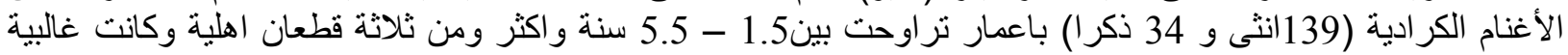

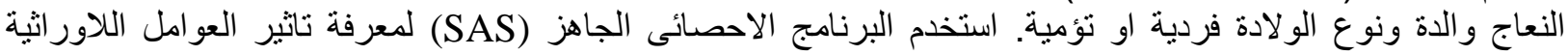

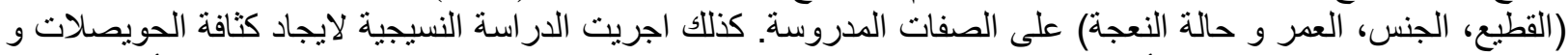

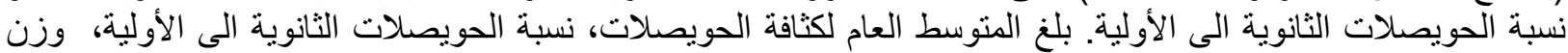

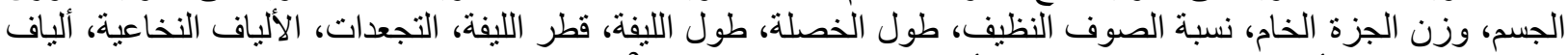

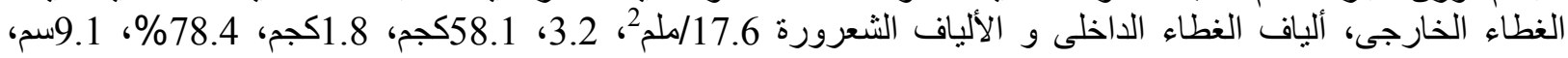

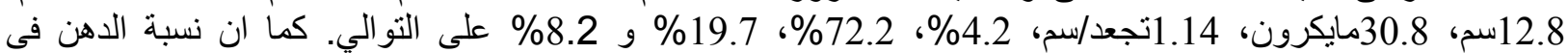
الصوف الخام بلغت 8.2\%. كان للقطيع التأثير المعنوى على معظم صفات الصوف واف المدروسة. أنتجت الذكور اثقل وزنا للجسم وللجزة و اطول الألياف واعلى نسبة لألياف الغطاء الخارجى ولكن اقل نسبة لألباف الغطاء الداخلى عما عليه فى الغي

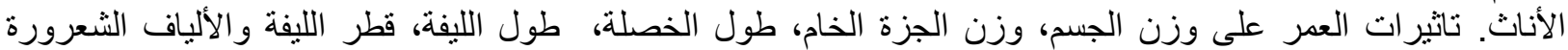

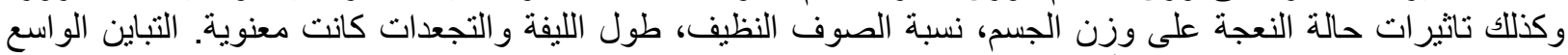

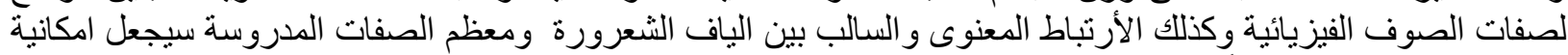

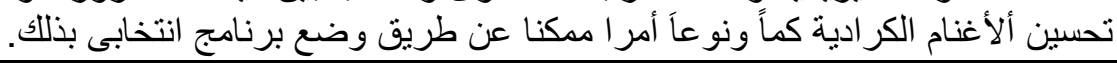

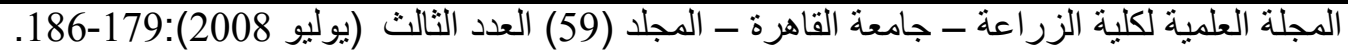

